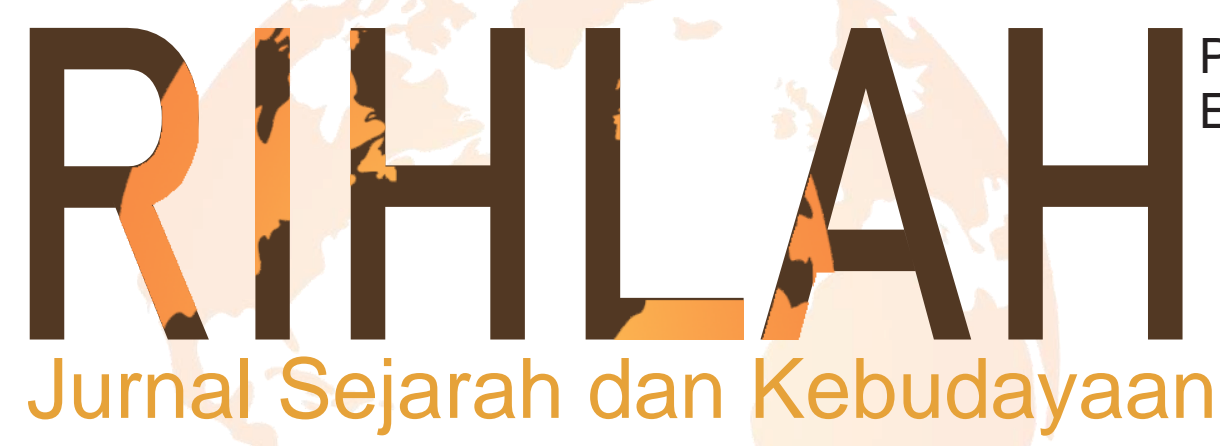

P-ISSN: 2339-0921

E-ISSN: 2580-5762

Pengaruh Bugis di Tanah Melayu dalam Perspektif Sejarah Sosial Politik Saepuddin

Akulturasi Budaya: Adat Pernikahan di Kelurahan Cikoro Kecamatan Tompobulu Kabupaten Gowa St. Hajar, M. Dahlan M, Syamzan Syukur

Corry Van Stenus, Perempuan dalam Perjuangan Abdul Qahhar Mudzakkar (1950-1965) Nurul Azizah

Sejarah dan Penyebaran Islam di Asia dan Afrika Herman Wicaksono

Sarekat Islam Penggagas Nasionalisme di Indonesia Soraya Rasyid, Annisa Tamara

Bergerak dengan Dua Sayap: Fenomena Gerakan Dakwah dan Politik Hizbut Tahrir di Indonesia Pasca Reformasi Aksa 


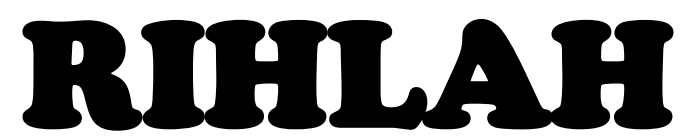

Jurnal Sejarah dan Kebudayaan

\begin{tabular}{|c|c|}
\hline Editor in Chief & Dr. Rahmat, M.Pd. \\
\hline Managing Editor & Mastanning, S.Hum, M.Hum. \\
\hline Editorial Board & $\begin{array}{l}\text { : Nur Ahsan Syukur, S.Ag, M.Si. } \\
\text { : Chaerul Munzir, S.Hum, M.Hum. } \\
\text { : Lydia Megawati, S.Hum, M.Hum. } \\
\text { : Muhammad Husni, S.Hum, M.Hum. } \\
\text { : Zaenal Abidin, S.S., M.H.I. } \\
\text { : Chusnul Chatimah Asmad, S.IP, M.M. } \\
\text { : Muhammad Arif, S.Hum, M.Hum. } \\
\text { : Nurhidayat, S.Hum, M.Hum. }\end{array}$ \\
\hline Desain Grafis & Nur Arifin, S.IP. \\
\hline Secretariat & Safaruddin, S.Hum. \\
\hline Reviewers & $\begin{array}{l}\text { : Prof. Dr. H. Abd. Rahim Yunus, M.A. } \\
\text { : Prof. Dr. H. Ahmad M. Sewang, M.Ag. } \\
\text { : Dr. Hj Syamzan Syukur, M.Ag. } \\
\text { : Dr. Nasruddin Ibrahim. } \\
\text { : Dr. Abd. Rahman Hamid. } \\
\text { : St. Junaeda, M.Hum. } \\
\text { : Dr. Rahmawati, MA. } \\
\text { : Dr. Nurhayati Syairuddin, M.Hum }\end{array}$ \\
\hline
\end{tabular}

Alamat Redaksi dan Tata Usaha : Jurusan Sejarah dan Kebudayaan Islam Fakultas Adab dan Humaniora UIN Alauddin Makassar, Jln. Sultan Alauddin No. 36 Samata Gowa Tlp. 0411-841879 Fax.0411-822140 (Kampus II) E.Mail. rihlah@uin-alauddin.ac.id

Jurnal Rihlah terbit dua kali dalam setahun, bulan Juni dan bulan Desember berisi kajian tentang Sejarah dan Kebudayaan, baik dari hasil penelitian maupun tulisan ilmiah lainnya.

Penyunting menerima tulisan yang belum pernah diterbitkan oleh media cetak lain. Naskah diketik spasi $1 \mathrm{~cm}$ pada kertas berukuran A4 dengan tulisan berkisar 12-23 halaman. Naskah yang masuk dievaluasi oleh Dewan Penyunting. Penyunting dapat melakukan perubahan pada tulisan yang dimuat untuk keseraganan format, tanpa mengubah maksud dan konten tulisan. 
Saepuddin $01-17$

Pengaruh Bugis di Tanah Melayu dalam Perspektif Sejarah Sosial Politik

St. Hajar, M. Dahlan M, Syamzan Syukur

Akulturasi Budaya: Adat Pernikahan di

Kelurahan Cikoro Kecamatan Tompobulu

Kabupaten Gowa

Nurul Azizah.

Corry Van Stenus, Perempuan dalam Perjuangan

Abdul Qahhar Mudzakkar (1950-1965)

Herman Wicaksono.

Sejarah dan Penyebaran Islam di Asia dan Afrika

Soraya Rasyid, Annisa Tamara

$66-84$

Sarekat Islam Penggagas Nasionalisme di Indonesia

Aksa

Bergerak dengan Dua Sayap: Fenomena Gerakan Dakwah

dan Politik Hizbut Tahrir di Indonesia Pasca Reformasi 


\title{
Sarekat Islam Penggagas Nasionalisme di Indonesia
}

\author{
Sorayah Rasyid \\ Annisa Tamara \\ Universitas Islam Negeri Alauddin Makassar \\ Sorayarasyid910@gmail.com \\ Annisatamara63@gmail.com
}

\section{Abstract}

This paper aims to describe the existence of Sarekat Islam and its contribution in developing the Indonesian nationalism awareness. This paper is a historical writing by relying on literary studies. The results showed that the struggle of Sarekat Islam in the national movement has been able to foster Indonesian awareness of human values and their dignity as a nation. This consciousness developed into a national awareness with the growth of national unity ties between the people of Indonesia. The struggle of Sarekat Islam also made the Dutch colonial government realize about the desire of Indonesian people to achieve independence. Internal conflicts have slowly divided Sarekat Islam, thus weakening its struggle in the national movement. However, Sarekat Islam played an important role in realizing the independence of the Republic of Indonesia. The struggle and the track record of Sarekat Islam have placed this organization as a pioneer of nationalism in Indonesia.

Keywords: Syarekat Islam, Nasionalism, Indonesian.

Tulisan ini bertujuan mendeskripsikankeberadaan Sarekat Islam dan kontribusinya dalam membangun kesadaran nasionalisme bangsa Indonesia.Tulisan ini merupakan tulisan sejarah dengan mengandalkan studi pustaka.Hasil tulisan menunjukan bahwa perjuangan Sarekat Islam dalam pergerakan nasional telah mampu menumbuhkan kesadaran rakyat Indonesia terhadap nilai manusia dan harga dirinya sebagai suatu bangsa.Kesadaran ini berkembang menjadi kesadaran nasional dengan tumbuhnya ikatan persatuan nasional antara rakyat Indonesia.Perjuangan Sarekat Islam juga menyadarkan pihak pemerintah kolonial Belanda terhadap keinginan rakyat Indonesia mencapai kemerdekaannya.Konflik internal secara pelan telah memecah Sarekat Islam sehingga melemahkan perjuangannya dalam pergerakan nasional.Meski demikian, Sarekat Islam tetap mempunyai peranan penting dalam mewujudkan kemerdekaan Republik Indonesia.Rekam jejak dan perjuangan Sarekat Islam telah menempatkannya sebagai organisasi pengagas Nasionalisme di Indonesia. 
Kata Kunci: Syarekat Islam, Nasionalisme, Indonesia.

\section{Pendahuluan}

Indonesia merupakan bangsa yang besar dan wilayah yang luas, dan memiliki banyak pulau terdapat berbagai macam ras, suku, agama dan budaya. Selama tiga abad atau kurang lebih tiga ratus lima puluh tahun bangsa Indonesia dijajah oleh Barat, maka selama itu pula masyarakat bangsa Indonesia berada dalam penindasan penjajah, pribumi Indonesia tidak mendapatkan hak asasi manuisa (HAM) mereka selalu ditindas, disiksa, dijadikan budak oleh penjajah, dan dalam bidang politik, pendidikan, perekonomian dikuasai oleh pemerintah kolonial Hindia Belanda.Maka dalam memerdekakan Indonesia dari penjajah muncullah Pergerakan Nasionalisme yang bertujuan menyadarkan dan memajukan masyarakat bangsa Indonesia, dan sebelum abad ke dua puluh penduduk mayoritas Indonesia adalah muslim maupun sampai saat ini. Salah satu intelektual muslim Indonesia terpacu untuk membentuk sebuah perkumpulan Islam yang mempermudah masyarakat dalam mencapai suatu tujuan dengan Visi dan Misi yang sama.

Pada abad ke dua puluh Pergerakan Nasionalisme sudah berkembang dan meluas berbagai macam organisasi-organisasi bermunculan, seperti Sarekat Islam (1912), Budi Utomo (1908) mewakili nasionaliseme Jawa, Panguyuban Pasundan (1914) mewakili nasionalisme Sunda, Serikat Sumatera (1919) mewakili Nasionalisme Sumatera dan sebagainya. Perkumpulan tersebut mempunyai sejarah masing-masing atas lahirnya organisasi tersebut. ${ }^{1}$ Organisasi Sarekat Islam (SI) ini sebelumnya adalah organisasi Sarekat Dagang Islam (SDI) 1905 didirikan atas dasar tujuan untuk membentengi para pedagang Batik di Solo terhadap pedagang Cina dan para bangsawan, pada masa penjajahan pemerintah kolonial Hindia Belanda memonopoli disemua bidang yang dilakukan mayarakat pribumi terutama perdagangan hingga perekonomian masysrakat berada dalam garis kemiskinan.Kemudian Sarekat Dagang Islam (SDI) 1905 berganti Nama menjadi Sarekat Islam (SI) 1912 dengan tujuan ingin membebaskan masyarakat Indonesia dari segala bentuk Penindasan dan diskriminasi oleh pemerintah Kolonial Hindia belanda. Dari masa ke masa Sarekat Islam telah mengalami perubahan nama hingga menjadi Partai politik pertamadi Indonesia, akan tetapi tujuannya tetap sama, ingin membebaskan masyarakat Indonesia dari penindasan dan diskriminasi yang dilakukaan oleh penjajah.

Penindasan dan diskriminasi oleh penjajah membuat resah penduduk pribumi, dari sini terpaculah seorang intelektual muslim untuk membuat perkumpulan agar memudahkan untuk mencapai tujuan bersama, yakni Haji

${ }^{1}$ Anton Timur Djaelani, Gerakan Sarekat Islam (Cet; I Jakarta: LP3ES, 2017), h. 23. 
Samanhudi mendirikan organisasi Sarekat Dagang Islam (SDI) pada tahun 1905 di Solo ${ }^{2}$. Kebangunan kembali minat kepada agama Islam dan ancaman persaingan dari pedagang Cina, maka Haji Samanhudi seorang pedagang batik di Solo tepatnya di kampung Lawean telah merencanakan mendirikan organisasi untuk para pedagang Islam bangsa Indonesia di Solo. Masyarakat solo sangat antusias menyambut organisasi SDI ini, karena sudah sangat lama membutuhkan perkumpulan yang mampu menyatukan masyarakat di Solo untuk melawan penjajah karena telah memonopoli perdagangan bangsa Indonesia.Pada tanggal 10 September 1912 Sarekat Dagang Islam berubah Menjadi Sarekat Islam (SI) dengan tujuan agar organisasi ini tidak hanya berfokus kepada para pedagang Indonesia namun juga bisa membantu masyarakat bangsa Indonesia dalam segala bidang dan menjadikan bangsa Indonesia merdeka dari penjajah. Penindasan, kekejaman, dan diskirminasi yang dialami masyarakat bangsa Indonesia harus ditiadakan ${ }^{3}$. Harun Nasution seorang pemikir Islam pada abad ke 20 mengatakan Islam yang pertama yang berbentuk republik atau berdasarkan demokrasi, dan dalam al-Quran secara global mengandung 3 unsur utama yaitu; unsur Ibadah, unsur Syariah dan unsur Muamalah. Dari tiga unsur pokok utama tersebut dijabarkan dalam kehidupan sehari-hari.Dan rasa kebangsaan merupakan penjabaran unsur muamalah maka rasa cinta pada bangsa adalah suatu panggilan Islam dikarenakan inti persoalan ajaran Islam adalah mengajak manusia kepada jalan yang benar ${ }^{4}$.

Islam dan umat muslim berperan besar dalam memerdekakan bangsa Indonesia, salah satu perkumpulannya yang berperan besar adalah Sarekat Islam. organisasi Sarekat Islam ingin memerdekakan bangsa Indonesia sesuai dengan ajaran Islam dari itu peneliti tertarik dan menganggap penelitian ini penting untuk dilaksanakan karena Sarekat Islam sebagai organisasi nasionalisme yang ideologinya ada nilia-nilai Islam. Kemudian dari penelitian sejarah Ini dijadikan acuan untuk menata kehidupan masyarakat bangsa dan untuk negara kedepannya, bahwa segala sesuatu yang didasari niat baik dan ikhlas karena Allah maka disitu ada pertolongan Allah.Dari uraian latar permasalahan diatas dapat dirumuskan pokok masalahnya adalah Peranan Sarekat Islam dalam mewujudkan kemerdekaan republik Indonesia.

2. Novian Dwi Cahyo,"Peranan H. Samanhudi dalam Sarekat Dagang Islam”, Skripsi (Makassar Fak. Adab dan Humaniora UIN Alauddin, 2018), h. 7.

${ }^{3}$ Ahmad Mansur Suryanegara, Api Sejarah (Mahakarya Perjuangan Ulama dan Santri DalamMenegakkan Negara Kesatuan Republik Indonesia, Vol. 1 (cet. Iv, Bandung : Penerbit Surya Dinasti.2018), H. 375-377.

${ }^{4}$ Harun Nasution, "Pembaharuan dalam Islam Sejarah Pemikiran dan Gerakan", dalam Muhammad Tamrin, "Islam dan Nasionalisme Indonesia”, Skripsi (Ujung Pandang, Fak. Adab IAIN Alauddin”,1997), h. 2. 


\section{Muncul Semangat Nasionalisme di Indonesia}

Lahirnya nasionalisme di Indonesia akibat dari kedatanagn Belanda ke Nusantara menjadikannya tanah jajahan, Belanda datang ke Indonesia dengan tujuannya kapitalisme dan imperialisme dengan kata lain adalah gold, glory, gospel. Sejak indonesia dijadikan tanah jajahan oleh Belanda membuat bangsa Indonesia rugi baik dalam bidang ekonoimi, struktur kehidupan sosial budaya dan politik. Penduduk pribumi Indonesia menganut agama Islam kita ketahui kedatangan Belanda disamping imperialisme dan kapitalisme juga diboncengi penyebaran agama atau disebut gospel. Misionaris Belanda ini diilhami akibat "Perang Salib" atau perang suci, bagi kaum muslim kapitalisme dan imperialisme dan misionaris merupakan musuh besar yang wajib diperangi. Sejarah mencatat ulama pemimpin-peminpin Islam tampil membela bangsa, negara dan Agama Islam, "Perang Paderi" dipimpin oleh ulama Muhammad Syahab yang lebih dengan Tuanku Imam Bonjol serta perang di Ponegoro, perang Sulta Hasanuddin dan lainlain

Semangat persatuan ukhuwah Islamiyah yang menjadi perekat perjuangan terwujudnya sebagai panggilan memerangi kemaksiatan dan membela kebenaran. Sebab itu lahirnya semangat nasionalisme merupakan manifestasi potensi sesungguhnya Islam di Indonesia ${ }^{5}$.Kekuatan gerakan Islam bangkit mendobrak kejahatan atau kedzoliman penjajahan dimana penduduk Indonesia ditindas, diskriminasi, berada dalam garis kemiskinan, keterbodohan, dimana belanda mengadakan kerja tanam paksa, petani hanya mendapatakan hasil kerja yang sedikit dan pembayaran pajak yang tinggi untuk memakmurkan pemerintah kolonial Belanda, Belanda memonopoli Indonesia di segala bidang termaksud bidang ekonomi dan politik. Bahwa perbuatan tersebut menurut ajaran Islam bahwa perintah Allah SWT wajib seorang muslim harus mencegah perbuatan mungkar maka nasionalisme dipandang dari prespektif Islam adalah panggilan Islam. Serupa dengan penjelasan Lothrop Stoddard dalam bukunya: Hakekat perjuangan nasional bangsa Indonesia adalah hakekat perjuangan ummat Islam Indonesia, yang disoroti oleh sinarnya salaf, kemudian membestral gerakan modornis dan gerakan nasional pada umumnya. Jiwa nasional dengan jiwa cinta kepada daerah masing-masing, masih bersifat kedaerahan, seperti kebangsaan Jawa, Sunda Sumatera, Bugis dan sebagainya. Jurang pemisah antara daerah-daerah itu senantiasa deperdalam dan dipelihara oleh kolonial, tak lain sebab takut akan persatuan seluruh bangsa Indonesia, jiwa nasional ${ }^{6}$.

\footnotetext{
${ }^{5}$ Muhammad, Tamrin, "Islam danNasionalisme Indonesia", Skripsi(Ujung Pandang:Fak. IAIN Alauddin, 1997), h. 50.

${ }^{6}$ Lothrop Stoddard, DuniaBaru Islam, (Jakarta: PanitiaPenerbitDuniaBaru Islam, 1996), h. 328. 
Dalam kaitannya gerakan-gerakan Islam yang mengancam stabilitas Kolonialisme Belanda di Indonesia, dan pada tahun 1848 di Negara Belanda terjadi sebuah perubahan politik, yaitu berkat kemenangan kaum liberal, sehingga menjadikan pemerintah Belanda diubah berdasarkankan aliran liberalisme Belanda pun merubah gaya politik kolonialnya dan menjalankan politik barunya yaitu politik etis, Politik etis ini yaitu, pemerintah kolonial Belanda membangun irigasi emigrasi dan edukasi tujuan politik etis ini agar meningkatkan kesejahteraan masyarakat pribumi Indonesia melalui irigasi, edukasi, dan emigrasi adapun tujuan lainnya yaitu untuk mengimbangi pergerakan-pergerakan Islam yang semakin terbuka di Indonesia?

Namun politik etis ini membuat kesadaran nasionalisme masyarakat Indonesia lebih tinggi, dampak dari politik etis ini melahirkan intelektual yang kemudian melahirkan gerakan intelektualistik untuk memerdekakan Indonesianya. Ditandaskan bahwa lahirnya kesadaran semangat nasionalisme di Indonesia dipengaruhi beberapa faktor utama yaitu sebagai berikut: Pertama, Agama Islam dianut oleh masyarakat Indonesia sekitar 90\%, agama Islam dianut berbagai daerah di seluruh pelosok Indonesia. Karena persamaan keyakinan ini terbentuknya kesatuan agama bangsa Indonesia dan lahirnya solidaritas perlawanan terhadap pemerintah kolonial Belanda.Kedua, Islam di Indonesia sudah berkembang sejak lama dan pengaruh Islam semakin kuat dan meluas di Indonesia ketika terjadi penindasan oleh pemerintah kolonial Belanda yang menerapkan imperialisme Protestan Belanda, Karena salah satu tujuan datangnya Belanda ke Indonesia adalah melaksanakan Gospel. Belanda ingin menggantikan perialis Katolik Portugis menjadi agama Protestan Belanda.Ketiga, faktor lain yang menyebabkan lahirnya semangat nasionalisme di Indonesia adanya perkembangan bahasa Melayu pasar yang berubah menjadi Bahasa persatuan Indonesia.Perubahan ini terjadi karena kebijaksanaan kerajaan Protestan Belanda dalam usahanya untuk melestarikan penjajahannya dengan menciptakan rasa rendah diri umat Islam (inferiority).

Untuk menciptakan kondisi umat Islam agar tetap berada dalam kondisi inferiority umat Islam dilarang menggunakan bahasa Belanda atas perintah pemerintah kolonial Belanda dan kemudian umat Islam menjadikan bahasa Indonesia sebagai senjata kejiwaan yang sangat ampuh (the terrible psychological weapon) Sebagai ekspresi atas aspirasi Semangat perjuangan nasionalisme Indonesia. Lahirnya semangat nasionalisme di Indonesia juga dikarenakan pribumi Indonesia sebagai masyarakat Indonesia yang dijajah oleh pemerintah kolonial Belanda mengalami berbagai macam penindasan, tekanan, pemaksaan, permainan

${ }^{7}$ Muhammad, Tamrin, "Islam dan Nasionalisme Indonesia", Skripsi (Ujung Pandang: Fak. Adab IAIN Alauddin, 1997), h 51. 
politik yang dijalankan pemerintah kolonial Belanda baik dalam perekonomian, perdagangan, pendidikan Indonesia dan sebagainya karena keadaan demikian bangsa Indonesia dikuasai oleh pemerintah kolonial Belanda. Dan berkembangnya pergerakan Pan-Islamisme yang dikenalkan oleh Jamaluddin Al-Afgahani pada tahun 1839-1897 kemudian didukung oleh Sultan Ottoman Abdul Hamid II pada awal abad ke-20, sebagai bukti laporan seorang penasehat Pribumi yang diutus oleh pemerintah ialah Rinkes memberikan laporan bahwa fenomena yang sedang terjadi di pantai timur Sumatera, pada tanggal 11 Desember 1914.

Sejak negara Belanda ikut campur dalam kekuasaan bangsa Indonesia dan melalui dagang VOC (Verenigde Oest Indische Compagnie), VOC adalah usaha yang dilakukan pemerintah kolonial Belanda untuk menguras kekayaan bangsa Indonesia oleh suatu kongsi dagang kemudian kongsi dagang itu dilindungi oleh pemerintah kolonial Belanda, mengakibatkan beberapa kerajaan yang berada di pesisir Indonesia dan pedagang-pedagang besar yang ada di Indonesia hancur serta meningkatnya kemiskinan pribumi Indonesia, keadaan pribumi Indonesia semakin memburuk setelah diterapkannya stelsel liberal.Stelsel liberal merupakan politik diberinya kebebasan terhadap beroperasinya modal-modal swasta Belanda dan negara asing lainnya.Pemerintah kolonial Belanda menjadikan bangsa Indonesia sebagai negara kuli dan kuli di antara negara-negara lainnya, menjadikan Indonesia sebagai hasil kekayaan negara-negara lainnya, Belanda menggali dan menghisap kekayaan yang ada di Indonesia.Kondisi seperti itu sangat tidak menguntungkan pemerintah Belanda karena daya beli rakyat menjadi melemah sehingga tidak mencukupi kebutuhan penjajahan.maka dari itu pemerintah kolonial Belanda mengangkat taraf kehidupan masyarakat dengan menerapkan politik etis, inti dari politik etis ini yaitu memperbaiki pengairan (irigasi), perbaikan dalam bidang pendidikan (edukasi), dan pemindahan penduduk (transmigrasi). Atau masyarakat Indonesia menyebutnya sebagai imperialisme kebudayaan yang halus dan jahat ${ }^{8}$.

Keterbelakangan dan kerusakan yang dialami rakyat Indonesia sudah meliputi diberbagai segala bidang kehidupan semua itu terjadi akibat sikap penjajah terhadap bangsa Indonesia, Belanda menguasai, memonopoli, membodohkan, memecah, melakukan diskriminasi, penindasan, tekanan, danpemaksaan. Kelompok Islam dipandang dalam segi sosial dapat ditanggapi perasaan rendah diri namun sejarah telah membuktikan bahwa karena ketaatan umat Islam di Indonesia terhadap ajaran Islam baik yang di pedesaan menyebabkan merasa tidak mungkin menerima pemerintah kolonial Belanda sebagai pemerintahan yang sah danlanggeng, hingga penduduk desa yang paling tidak berpendidikan sekalipun

${ }^{8}$ C.S.T. Kansil dan Julianto, Sejarah Pergerakan Kebangsaan Indonesia, (Jakarta: Erlangga, 1977), h.19. 
beranggapan sama.Tekanan dan penderitaan yang terus-menerus dirasakan masyarakat berbagai macam penindasan yang dibuat menjadikan rakyat miskin, menderita, tertekan, perlakuan yang dialami bersama itulah yang menimbulkan perasaan senasib dan akhirnya berwujud menjadi semangat nasionalisme, di Indonesia untuk kemerdekaan membebaskan diri dari belenggu penjajah.

\section{Sarekat Islam Sebagai Partai Politik Pertama dan Partai Politik Islam}

Setelah Sarekat Islam terpecah belah menjadi SI merah dan SI putih, tantangan Sarekat Islam untuk memajukan taraf kehidupan masyarakat Indonesia berdasarkan ajaran Alquran dan Sunnah mendapat perlawanan dengan SI merah yang berpahamkan ideologi komunis yang dibawakan oleh Marx, menyebabkan Sarekat Islam mendapatkan pukulan semakin berat dengan kaum komunis PKI. Para pemimpin dari Sarekat Islam berupaya untuk menemukan jalan agar dapat mempertahankan organisasi dan menyelamatkan organisasi beserta ajaran Islam dari kemunduran jauh akibat komunis salah satu upaya yang dilakukan Sarekat Islam itu dengan membentuk pasukan 2 front, peran tersebut yaitu tu cita-cita nasional untuk menentukan nasib sendiri dibentuk dalam Kongres nasional yang disebut "Kongres Hindia Nasional" dan yang satu untuk memperjuangkan dan mempertahankan kesatuan pandangan ideologi serta bekerja sama nama seluruh umat Islam dalam berbagai masalah yang muncul yang bersangkutan dengan Islam. Perpecahan SI terus berlanjut hingga pada pertemuan tanggal 16 Juli 1922 terjadi konflik antara SI merah dan SI putih, Haji Oemar Said Tjokroaminoto menjelaskan kondisi tersebut pada pertemuan Sarekat Islam di Ambarawa pada Agustus 1922, mengatakan: 1. Sudah menderita karena kemiskinan dan kekurangan, seperti halnya masyarakat, 2. Jawa, Sarekat Islam juga menderita keterbelakangan ${ }^{9}$.

Meskipun demikian terdapat berbagai jenis sosialisme jenis sosialisme yang digunakan Sarekat Islam adalah yang diberikan oleh Allah yakni Islam satu-satunya menjadi pedoman umat muslim. Sarekat Islam tidak hanya berjuang semata-mata ingin memerdekakan Indonesia dari penjajah namun menjadikan menjadikan misi Sarekat Islam sebagai pemersatu umat dan mengajarkan tentang umat ajaran Islam lebih baik berkembangnya paham komunisme di Indonesia Oemar Said Tjokroaminoto Mengadakan kongres Islam pertama di Cirebon pada bulan Oktober tahun 1922 tujuan dari Kongres tersebut:

1. Meminimalisir bahaya dari perbedaan pendapat diantara umat Islam berkenaan dengan detil-detil atau cabang-cabang masalah Islam serta berbagai masalah keagamaan yang diperselisihkan.

\footnotetext{
${ }^{9}$ Anton Timur Djaelani, Gerakan Sarekat Islam (Cet.1, Jakarta, LP3ES, 2017), h. 99.
} 
2. Berupaya untuk menggalang kesatuan dan kerjasama di antara umat Islamberkenaan dengan masalah keagamaaan ${ }^{10}$.

Bertambahnya pengetahuan pengalaman dan tantangan yang semakin berat pemimpin Sarekat Islam merasakan perlu adanya perbaikan tujuan pertama didirikannya Sarekat Islam dapat tercapai maka Sarekat Islam bertransformasi menjadi partai politik, namun yang menjadi partai politik hanyalah Central Sarekat Islam dikarenakan cabang-cabang Sarekat Islam di daerah tidak memiliki inisiatif dan sudah tidak memiliki ikatan yang kuat dengan Sarekat Islam Pusat akibat dari kebijakan pemerintah kolonial Belanda yang memberikan Sarekat Islam lokal untuk berdiri sendiri namun mendirikan Central Sarekat Islam sebagai pemersatu Sarekat lokal dengan pusat, namun Kaum komunis menajdikan kesempatan untuk menyebarkan ideologi Marx ke cabang lokal, agar Sarekat Islam tetap bersatu dalam kondisi seperti itu maka dibuat peraturan disiplin partai dan bai'at. praktik bai' at dilarang oleh pemerintah kolonial Belanda ${ }^{11}$. sedangkan disiplin partai mendapatkan serangan dari kaum komunis.

Pada kongres nasional ke-7 Central Sarekat Islam dilaksanakan pada tanggal 17 hingga 20 Februari 1923 di Madiun, pada kongres ini pembahasan penting yaitu transformasi Sarekat Islam menjadi partai politik .Pidato yang disampaikan oleh Haji Agus Salim menjelaskan bahwa organisasi Sarekat Islam mulanya berupa perkumpulan-perkumpulan lokal secara sukarela diikat oleh suatu badan Sentral sesuai dengan kehendak pemerintah kolonial Belanda.bentuk organisasi seperti tersebut mendapat halangan pertumbuhan gerakan secara bebas, dan kemudian Central Sarekat Islam tetap bertanggung jawab terhadap apa yang terjadi di cabangcabang lokal meskipun organisasi CSI terpisah dari Sarekat Islam lokal. Ikatan yang lemah antara CSI dengan cabang-cabangnya memungkinkan perkumpulan lain untuk menginfiltrasi dan menarik pengikut-pengikutnya seperti yang dilakukan oleh SI merah, SI merah mengambil kesempatan itu untuk menyebarkan ideologi komunis pemimpin Sarekat Islam berpendapat perlu adanya pembaharuan inovasi untuk menghadapi tantangan tersebut maka Sarekat Islam berubah menjadi partai Sarekat Islam yang dimana anggota-anggotanya harus aktif bukan hanya sekedar anggota dimana setiap cabang-cabang Sarekat Islam yang akan membuat propaganda untuk bekerja menurut prinsip-prinsip dasar dan program yang tercantum dalam statute partai dan para anggota Sarekat Islam diminta agar tetap setia pada ajaran Islam yang berkaitan dengan persoalan sosial dan perintahperintahnya mengenai dunia.

10 Almez H.O.S Tjokroaminoto Hidup dan Perjuangannya, (Vol. 1, Jakarta: Bulan Bintang, 1952), h. 101.

${ }^{11}$ Kahin, Nationalism and revolution in Indonesia, h. 102. 
Sebagai partai politik partai Sarekat Islam hanya akan menyatukan perjuangan politik umat Islam jam dengan membolehkan setiap anggotanya untuk mempertahankan pandangan dan kebebasan mereka untuk mengikuti jalan masingmasing menuju kebahagiaan dunia dan akhirat. Rakyat yang tertindas oleh pemerintah kolonial Belanda yang tidak memiliki kebebasan dan hak untuk berbicara maka keharusan untuk membentuk sebuah partai politik yang utuh.dapat dismpulkan hasil kongres kali ini, ialah:Pertama. Memperbarui bai'at atau sumpah sebagai janji kesetiaan.Kedua.Bersikap non koperasi dengan pemerintah kolonial Belanda.Ketiga.Konfirmasi tentang berlakunya disiplin partai kepada PKI dan transformasi gerakan Sarekat Islam menjadi partai Sarekat Islam yang disingkat menjadi PSI ${ }^{12}$.

Dengan berubahnya organisasi pergerakan Sarekat Islam menjadi partai Sarekat Islam (PSI), perjuangan kaum nasionalis Islam Indonesia memasuki tahap baru, ideologi, prinsip dan tujuannya masih tetap sama, hanya saja bentuk organisasi tersebut berubah menjadi partai politik yang berfungsi penuh dan terintegrasi sehingga siap untuk melakukan tugas beratnya.

\section{Perjuangan Sarekat Islam dalam Pergerakan Nasional Indonesia}

Usaha Sarekat Islam dalam pergerakan nasional di Indonesia dapat diketahui dari berbagai segi upayanya untuk ikut serta memperjuangkan kemerdekaan bangsa dan negara Indonesia berikut beberapa upaya yang dilakukan Sarekat Islam dalam mewujudkan kemerdekaan Republik Indonesia:

1. Usaha yang dilakukan Sarekat Islam untuk meningkatkan derajat kehidupan rakyat Indonesia dalam upaya tersebut menumbuhkan dan meratakan kesadaran nasionalisme, sebgagas nasionalisme.

2. Gerakan aspirasi rakyat dalam menuntut hak-hak sebagai suatu bangsa serta partisipasinya di dalam pemerintahan.

3. Membangun persatuan dan kekuatan nasionalisme dalam upayanya mempertahankan semangat dan kesatuan usaha di dalam perjuangan pergerakan nasional.

Upaya yang dilakukan Sarekat Islam dalam memerdekakan Republik Indonesia sebagai pergerakan nasional didukung oleh segenap rakyat Indonesia maka Sarekat Islam berusaha untuk membangun kembali kesadaran akan harga dirinya sebagai rakyat Indonesia dan sebagai suatu bangsa yang seharusnya memiliki pemerintahan sendiri. kegiatan dilaksanakan karena aku menumbuhkan semangat

\footnotetext{
${ }^{12}$ Ahmad Mansur Suryanegara, Api Sejarah (Mahakarya Perjuangan Ulama dan Santri DalamMenegakkan Negara Kesatuan Republik Indonesia, Vol. 1 (cet. Iv, Bandung : Penerbit Surya Dinasti.2018), h. 42.
} 
nasionalisme Indonesia, Dalam upaya ini Sarekat Islam ikut serta berusaha meningkatkan derajat kehidupan rakyat Indonesia melalui perjuangannya di bidang ekonom, sosial, politik, dan keagamaan ${ }^{13}$. Membangun kembali semangat berusaha di bidang ekonomi rakyat guna memperbaiki perekonomian rakyat Indonesia.

Meningkatkan status sosial rakyat dengan menolak segala perbuatan yang sewenang-wenang terhadap rakyat pribumi.tidak menghendaki adanya perbedaanperbedaan yang merendahkan martabat rakyat serta berusaha mewujudkan sikap persaudaraan dan kebersamaan di antara rakyat Indonesia. Mengusahakan perbaikan pendidikan serta praktek kehidupan beragama yang sesuai ajaran Islam kepada rakyat Indonesia kegiatan tersebut Sarekat Islam juga bermaksud memperbaiki segi moral rakyat Indonesia yang karena akibat penjajah mengalami kemerosotan seperti, tertanamnya jiwa membudak, rendah diri dan takut membela yang seharusnya menjadi hak-hak pribumi. para pemimpin Sarekat Islam menganggap tugasnya yang paling utama adalah untuk menyadarkan rakyat terhadap hak-haknya yang dilindungi oleh pemerintah, Terhadap ketidakadilan dan kesewenang-wenangan ${ }^{14}$, melalui kegiatan-kegiatan tersebut, Sarekat Islam menjadi pusat pembelaan rakyat yang pertama lahir di Indonesia, di dalamnya berkumpul anggota dari bermacam-macam status sosial dan dari berbagai daerah di seluruh Indonesia, pandangan serta berbagai harapan yang ingin diperoleh melalui Sarekat Islam mematangkan diri dalam kesatuan keanggotaan Sarekat Islam. Anggotaanggota Sarekat Islam yang berasal dari hampir seluruh wilayah di Indonesia dengan agama Islam sebagai ikatan pemersatunya untuk mewujudkan berbagai kesadaran utamanya yang mengarah kepada kesadaran berbangsa dan bernegara.Hal itu dapat diketahui pada kongres-kongres nasional Central Sarekat Islam, yang diikuti oleh wakil-wakil dari seluruh Sarekat Islam lokal dari berbagai daerah di Indonesia, berkumpul dan bersama-sama membicarakan segala sesuatu yang berkaitan dengan kehidupan warganya di segala aspek bidang kehidupan.

Upaya Sarekat Islam berikutnya yaitu mengemukakan segala sesuatu yang dirasakan dan diinginkan oleh rakyat dalam memperoleh kembali hak-haknya sebagai suatu bangsa serta keikutsertaan rakyat di dalam pemerintahan di Indonesia kesemuanya itu dihimpun dan kemudian dibahas oleh para pemimpin Sarekat Islam dan selanjutnya diajukan kepada pemerintah Kolonial Belanda agar diperhatikan ataupun dilakukan perbaikan-perbaikan terhadap segala sesuatu yang diinginkan oleh rakyat Indonesia. Hal ini dilaksanakan dikarenakan Sarekat Islam begitu percaya terhadap maksud baik pemerintah sehubungan dengan dilakukannya politik etis, sehingga Sarekat Islam kelihatannya juga mau

${ }^{13}$ A. P.E. Korver, Sarekat Islam Sebagai Ratu Adil, (Jakarta, Grafiti Press, 1985), h. 89

${ }^{14}$. A. P.E. Korver, Sarekat Islam Sebagai Ratu Adil, (Jakarta, Grafiti Press, 1985), h. 89 Jurnal Rihlah Vol. 8 No.1/2020 
bekerjasama dengan pemerintah untuk mengadakan perbaikan kehidupan rakyat pribumi Indonesia ${ }^{15}$.Sarekat Islam dengan kongres-kongresnya merupakan kekuasaan tertinggi Dalam organisasi tersebut dan sejak tahun 1916 kongres tersebut disebut dengan kongres nasional Central Sarekat Islam, yang berupaya menghimpun berbagai aspirasi dan keinginan rakyat tentang segala sesuatu yang terjadi di lingkungannya yaitu berupa keluhan maupun harapan dan juga dibicarakannya bermacam-macam masalah mulai dari ekonomi sampai politik.

Kongres juga digunakan sebagai forum untuk mendidik rakyat tentang masalah-masalah tertentu yang dicetuskan dalam bentuk gagasan serta pemikiran para pemimpin Sarekat Islam di dalam memahami keadaan yang tengah berlangsung di masyarakat ataupun terhadap keinginan keinginan masyarakat yang disampaikan kepada mereka ${ }^{16}$.Adapun tuntutan tuntutan Sarekat Islam kepada pemerintah sebagai berikut:Pertama, sehubungan dengan adanya rencana kewajiban militer terhadap rakyat Indonesia, Sarekat Islam mengemukakan bahwa kemungkinan dilakukannya prestasi-prestasi militer oleh rakyat, haruslah diikuti dengan pemberian imbalan dengan perluasan hak-hak politiknya. Selama hal itu belum dinyatakan, Sarekat Islam hanya mengungkapkan bahwa Apabila terjadi serangan dari luar negeri, iya tidak ingin memberikan bantuan apapun terhadap pihak pemerintah.Di dalam mosinya yang dikeluarkan oleh pengurus Sentral Sarekat Islam pada bulan Agustus 1916, menyatakan persetujuannya dengan tujuan pertahanan Indonesia, dengan mengemukakan keluhan dan tuntutannya terhadap pemerintah yaitu, tentang kekecewaan rakyat terhadap kesenangan kesenangan dan sikap pemaksaan penindasan dari kalangan pamong praja dan swasta Belanda, apabila kekecewaan tersebut tidak diatasi, maka jika atau mungkin rakyat Indonesia tidak ingin membantu ${ }^{17}$.

Selanjutnya dikemukakan kewajiban milisi dikaitkan dengan tuntutan adanya pemerintahan sendiri. Hak-hak politik yang dimiliki oleh rakyat Indonesia sama sekali tidak sebanding dengan kemungkinan berlakunya kewajiban untuk berperanserta dalam pertahanan Indonesia. Oleh karena itu pelaksanaan kewajiban militer haruslah bersamaan dengan pemberian hak-hak politik lebih banyak, agar rakyat Indonesia menganggap kewajiban militer ini sebagai soal nasional dan dengan baik menerimanya. Pengaturan pertahanan Indonesia adalah soal yang akan dibicarakan dalam parlemen untuk itu rakyat Indonesia juga harus terwakili di dalam parlemen tersebut akhirnya dikemukakan tentang keadaan ekonomi rakyat Indonesia yang sangat buruk sehingga dirasa memberatkan bila pajak rakyat yang

${ }^{15}$. Moh. Yusuf, "Sarekat Islam Dalam Pergerakan Nasional Indonesia”, Skripsi, (Surabaya Fak. Adab IAIN Sunan Ampel, 1987), h. 83.

${ }^{16}$ Ibid.,

${ }^{17}$ Anton Timur Djaelani, Gerakan Sarekat Islam (Cet.1, Jakarta, LP3ES, 2017), h. 57. 
dinaikkan untuk memperkuat pertahanan yang direncanakan. Tuntutan Sarekat Islam tentang perluasaan penguasaan hak penguasaan hak-hak politik bagi rakyat Indonesia, sebagaimana dikemukakan oleh Haji Oemar Said Tjokroaminoto punya Pada kongres Sarekat Islam di Bandung tahun 1916 antara lain:

Kita berharap dengan sangat agar diadakan peraturan yang memberi kita penduduk pribumi hak untuk ikut serta dalam mengadakan bermacammacam peraturan yang sekarang sedang kita pikirkan. tidak bahwa perundang-undang untuk pria pribumi, bahwa diperintahkan tanpa kita dan tanpa mengikutsertakan pribumi... kita dengan dan bar di Republik, atau paling sedikit dewan penjajahan agar kita dapat ikut berbicara dalam urusan pemerintahan, Pemerintahan sendiri adalah perlu lebih lama lebih dirasakan bahwa tidak patut lagi Hindia diperintah oleh Netherland seperti Tuan Tanah mengurus percil-percil nya tidak pantas lagi memandang Hindia sebagai sapi perahan, yang hanya mendapat makanan dari susunya, susu nya tidak pantas lagi untuk memandang negeri ini sebagai tempat untuk didatangi dengan maksud mencari untung dan sekarang juga sudah tidak patut lagi bahwa penduduknya terutama putra dunia tidak punya hak untuk ikut bicara dalam urusan pemerintahan yang mengatur nasibnya ${ }^{18}$.

Selanjutnya Sarekat Islam juga menyusun instruksi khusus untuk wakilnya Abdul Muis yang akan menghadap kepada ratu Belanda menyampaikan masalah pertahanan Indonesia tersebut dengan mengajukan tuntutan agar pemerintah meningkatkan kesejahteraan rakyat, Kesehatan, pertanian, kerajinan dan perdagangan dengan memperluas pendidikan kejujuran serat memajukan peraturan perkreditan dan kumpulan koperasi.Dan juga mengajukan tuntutan agar memperluas pengaturan irigasi, menegakkan hak hak buruh dari tekanan yang dilakukan beberapa kepala desa dan diadakannya perubahan dalam beberapa ketentuan hukum khususnya dalam hal sewa $\operatorname{tanah}^{19}$. Kedua, Sehubungan dengan berdirinya dewan rakyat atau volksraad, maka Sarekat Islam mempergunakannya sebagai forum atau sarana aksi perjuangannya dan dapat bertindak sebagai penasehat bagi parlemen pemerintah Belanda serta sebagai rem terhadap anggota-anggota parlemen yang konservatif. Sarekat Islam berusaha mendudukan posisi rakyat yang sebenarnya dalam Volksraad serta fungsinya dalam pemerintah sehubungan dengan adanya dewan rakyat yang hanya sebagai sandiwara belaka tidak berfungsi sebagai lembaga legislatif tetapi hanya

${ }^{18}$ Muhammad Roem, Tiga Peristiwa Bersejarah, (PT. Sinar Hudaya, 1972), h.15. Dalam Moh. Yusuf, "Sarekat Islam Dalam Pergerakan Nasional Indonesia", Skripsi, (Surabaya Fak. Adab IAIN Sunan Ampel, 1987), h. 85

${ }^{19}$ Deliar Noer, Gerakan Modern Islam di Indonesia 1900-1942, (Jakarta, LP3S, 1980), h.133. 
mempunyai kekuasaan memberi nasehat atau saran kepada pemerintah usaha itu dikemukakan melalui mosinya yang diajukan kepada pemerintah kolonial Belanda pada tahun 1918 yang didukung sepenuhnya oleh segenap golongan di kalangan pergerakan.

\section{Hasil perjuangan Sarekat Islam Menjadi Pengagas Nasionalisme Indonesia}

Aktivitas Sarekat Islam dalam pergerakan nasional yang dilaksanakan dengan berbagai bentuk dan sifat kegiatannya untuk mencapai kemerdekaan Indonesia mampu menghasilkan hal-hal antara lain sebagai berikut: Perhatian Sarekat Islam terhadap kehidupan rakyat Indonesia berhasil memberikan kepada rakyat Indonesia perasaan bahwa mereka diperhatikan, dilindungi dan diperjuangkan, segala sesuatu yang dikeluhkan dan diinginkan rakyat Sarekat Islam memperjuangkan hak-hak mereka dengan memberikan tuntutan kepada pemerintah kolonial Belanda, adanya perasaan tersebut menumbuhkan kesadaran rakyat terhadap kondisinya yang serba terbelakang dalam segala aspek kehidupan, hal itu membangkitkan kembali semangat berusaha didalam memperbaiki taraf kehidupannya dan secara bertahap berkembang menuju pada Kesadaran Nasionalisme, sehingga SI disebut "Pengagas Nasionalisme Indonesia”.

Rakyat yang semula hanya mengetahui berbagai kewajiban yang dibebankan kepada mereka tanpa mengetahui apa yang menjadi hak mereka maka dengan kegiatan Sarekat Islam tersebut rakyat menjadi mengetahui terhadap apa yang semestinya menjadi hak-hak mereka dan harus mereka peroleh dari pemerintah, raja karena diperhitungkan ke eksistensinya, sebab Sarekat Islam memberikan rasa kebersamaan dan persaudaraan suatu hal yang tidak pernah mereka peroleh lagi sejak Indonesia dijajah oleh bangsa asing, masyarakat Indonesia pun menganggap dan memandang bahwa Sarekat Islam sebagai sebuah pergerakan yang akan membebaskan mereka dari penderitaan sejak datangnya penjajah, sebagaimana mereka menyaksikan bahwa gerakan Sari berani bertindak melawan ketidakadilan dengan gigih memperjuangkan keinginan rakyat untuk memperoleh perubahan kondisi yang lebih baik dan dengan bersungguh-sungguh memperhatikan serta menampung aspirasi rakyat untuk diajukan kepada pemerintah, sehingga SI disebut Ratu Adil. Punya kesadaran, rakyat akan nilai manusia dan harga dirinya tersebut berakibat pula tumbuhnya semangat rakyat berusaha dengan ikut serta, mereka secara aktif dalam usaha meningkatkan taraf kehidupan mereka, timbul pula keberanian rakyat untuk mengemukakan keluhan keluhan tentang segala kekurangan yang terjadi pada dirinya dan di lingkungan sekitarnya. 
Rakyat juga mampu mengajukan tuntutan tuntutan perbaikan baik melalui forum-forum yang diselenggarakan oleh Sarekat Islam ataupun yang disampaikan langsung kepada para pemimpin Sarekat Islam setempat. Kondisi rakyat yang demikian itu diakui dan disadari oleh Idennburg sebagai proses terbentuknya kesadaran rakyat seperti yang disebutkan dalam suratnya kepada Abraham kuyper: ...Rakyat Indonesia telah menyadari eksistensinya kepadanya telah dijelaskan bahwa tanahnya yang disewakan untuk budidaya gula jauh di bawah harga, bahwa terlalu sedikit upah kerja yang diterimanya dia menyadari bahwa keluhan di desa dan di kalangan para kepala Bumiputera rendahan tidak dipedulikan, bahwa penduduk Bumi Putra melalui turut bekerja untuk mengurus kepentingan sendiri dan berjaga-jaga terhadap kesenangan wewenangan.. ${ }^{20}$ Dalam sumber lain dikemukakan bahwa rakyat Indonesia telah memikirkan nasibnya dan tentang segala sesuatu yang terjadi di sekelilingnya inilah permulaan sadar dari tidurnya rakyat Indonesia ${ }^{21}$.

Sarekat Islam sebagai organisasi pergerakan nasional pertama yang menghimpun anggota anggotanya dari seluruh Indonesia mampu mengembangkan kesadaran rakyat Indonesia terhadap nilai manusia dan harga dirinya menjadi kesadaran dan semangat nasional yang membuahkan perjuangan rakyat di dalam pergerakan nasional kegiatan-kegiatan Sarekat Islam yang secara mudah mendapat dukungan rakyat Indonesia yaitu dapat memberikan sumbangan yang tidak kecil dalam artiannya bagi penyatuan Indonesia serta mendorong terbentuknya suatu ikatan berbangsa, yaitu bangsa Indonesia. Hal ini dapat diketahui bahwa pertentangan budaya dan etnis di kalangan rakyat Indonesia pada abad tersebut adalah sangat besar kondisi yang demikian itu senantiasa dipertahankan oleh pemerintah kolonial Belanda untuk kepentingan dan kelancaran penjajahannya.Maka keanggotaan sebagai merupakan dan tertentu pertentangan-pertentangan tersebut dan mempersatukan mereka keanggotaan yang ikatan ke agama.

Para pemimpin Sarekat Islam melakukan upaya yang sungguh-sungguh untuk mengorganisasikan penduduk seluruh Indonesia dari berbagai wilayah dalam suatu ikatan dan sampai pada tingkat tertentu mereka berhasil dalam usahanya tersebut kian merupakan kesempatan pertama Indonesia yang yang mungkin bagi untuk melaksana bentuk tentang berbagai permasalahan yang ada di tanah air.Hal itu makinmemperkuat tumbuhnya ikatan persatuan rakyat Indonesia dalam satu jalinan kebangsaan yaitu munculnya seangat

\footnotetext{
${ }^{20}$ A.P.E. Korver, Sarekat Islam Sebagai Ratu Adil, (Jakarta, Grafiti Press, 1985), h.55.

${ }^{21}$ Margono.Ictisar Sedjarah Pergerakan Nasional (1908-1945) (Jakarta: Dephankan Pusat Sejarah ABRI, 1971), h. 312.

Jurnal Rihlah Vol. 8 No.1/2020 
nasionalisme.Sarekat Islam dengan kongres-kongresnya juga dapat memainkan peranan "Pra Parlemen" bagi rakyat Indonesia dalam waktu sekian lama sebelum terbentuknya suatu perwakilan rakyat yang sejati di Indonesia.Central Sarekat Islam sebagai badan pusat dari cabang-cabang Sarekat Islam yang ada di berbagai wilayah di Indonesia dapat membantu menyalurkan keluh-kesah rakyat yang selama ini tidak dipedulikan oleh pejabat setempat, sebab rakyat merasa bahwa seringkali pengaduan yang sungguh layak tidak dipedulikan oleh kalangan pejabat setempat dan menganggap Sarekat Islam pusat lah yang telah membangunkan rakyat di mana-mana dan masih terus juga lebih membangunkannya, karena itulahkongres-kongres nasional Sarekat Islam juga merupakan semacam parlemen, yang membicarakan kepentingan kepentingan seluruh rakyat Indonesia serta membangkitkan nasionalisme.

Sarekat Islam telah banyak membangunkan pemikiran-pemikiran dan meletakkan landasan ataupun dasar bagi perjuangan rakyat dalam pergerakan nasional di Indonesia. Hazeu mengemukakan penilaiannya terhadap Sarekat Islam: ....Tidak pernah terbukti dengan jelas melainkan di Kongres ini bahwa berkenan dengan cara bagaimana Hindia diperintah, rakyat Sekarang menuntut agar ikut serta mengatur urusan negara dan bahwa pribumi tidak lagi seperti seperempat atau setengah manusia melainkan menuntut agar dipandang dan diperlakukan sebagai warga negara yang merdeka.. ${ }^{22}$.

Sarekat Islam dengan kegiatannya menghimpun dan menyalurkan aspirasi rakyat melalui tuntutan-tuntutannya atau mosi-mosinya pada pemerintah adalah tidakbanyak membawa perubahan yang berarti seperti yang diharapkan rakyat akan tetapi dengan kegiatan dan menghasil hal-hal sebagai berikut: Pertama, menjadikan Pemerintah dapat mendengarkan dan mengetahui tentang segala sesuatu yang menjadi keinginan rakyat yang sebenarnya, dalam hal ini pihak pemerintah kolonial Belanda terhadap apa yang dikeluhkan oleh rakyat pribumi dan diinginkannya perubahan adalah membenarkan seperti apa yang dikemukakan oleh pemimpin Sarekat Islam sebagaimana yang dikemukakan oleh seorang anggota dewan Hindia Belanda dalam laporan hasil penelitiannya tentang sebab-musabab perasaan tidak senangnya rakyat Sumatera Barat dan Selatan yaitu yang sampai pada kesimpulan bahwa dalam banyak hal membenarkan apa yang dikemukakan oleh pemimpin Sarekat Islam. Kedua, Sarekat Islam mendorong pemerintah untuk melakukan beberapa perubahan dan perbaikan terhadap kondisi yang di keluh-kesahkan oleh rakyat Indonesia seperti halnya yang dituntut oleh Sarekat Islam. Hal itu disebabkan oleh

\footnotetext{
${ }^{22}$ Moh.Yusuf, "Sarekat Islam Dalam Pergerakan Nasional Indonesia”, Skripsi, (Surabaya Fak. Adab IAIN Sunan Ampel, 1987), h.94.
} 
ketergantungan pemerintah terhadap mentalitas dan sikap pejabat Pamong Praja yang tidak memiliki pikiran yang cerah seperti pemerintah etis dan Indeburg dan Van Limburg Strum, juga ketergantungan pemerintah kolonial Belanda pada pemerintahan di negeri Belanda serta ketidakmampuannya untuk membatasi seluruh kehidupan perusahaan Eropa di Indonesia ${ }^{23}$.

Tuntuan rakyat kepada pemerintah Belanda tidak sesuai dengan harapan rakyat Indonesia namun berkat usaha Sarekat Islam pemerintah kolonial Belanda melakukan perbaikan antara lain:

1. Adanya perubahan tindakan oleh kalangan luas pejabat pemerintah yang telah menjadi jauh lebih baik, lunak dan berhati-hati dari keadaan sebelumnya serta tidak lagi sewenang-wenang dan seenaknya saja memperlakukan rakyat. Hal ini karena adanya instruksi di lingkungan pabrik gula untuk mencegah tindakan mudah mengeluarkan pemecatan, melarang dilakukannya pemukulan terhadap para buruh dan terhadap keluhan yang layak hendaknya diperhatikan

2. Pemerintah mulai memberikan hak-hak politik kepada rakyat Indonesia dengan mengikutsertakannya di dalam urusan pemerintahan, meskipun sangat terbatas sekali, seperti diikutsertakannya rakyat dalam lembaga dewan-dewan pemerintahan, baik dalam dewan rakyat dalam dewan-dewan daerah. Cabutnya larangan terhadap perkumpulan ketatanegaraan, yaitu dengan diakuinya hak penduduk untuk berkumpul dan berapat yang pelaksanaannya diatur dan dibatasi demi kepentingan umum dengan peraturan umum. Juga dikeluarkannya janji pemerintah kolonial Belanda kepada dewan rakyat pada bulan November 1908 untuk mengadakan perubahan-perubahan luas dalam bidang sosial dan konstitusi dikenal dengan sebutan janji November ${ }^{24}$

3. Banyaknya tuntutan atau mosi Sarekat Islam yang tidak direalisasikan oleh pemerintah kolonial Belanda, khususnya di bidang pemerintahan dewan rakyat (Volksraad) tetap dipertahankan sebagai badan penasehat. pemerintah juga melakukan pelanggaran ketatanegaraan seperti "Janji November" Hal ini menjadikan rakyat Indonesia tahun demi tahun semakin bertambah kekecewaan terhadap pemerintah kolonial Belanda.

Kekecewaan-kekecewaan tersebut menjadikan semakin tumbuhnya kesadaran rakyat Indonesia terhadap situasi hubungan kolonial yang ada di Indonesia yaitu dapat dipahaminya tentang adanya pertentangan antara

${ }^{23}$ A.P.E. Korver, Sarekat Islam Sebagai Ratu Adil, (Jakarta, Grafiti Press, 1985), h. 126-127.

${ }^{24}$ Muh.Yusuf, "Sarekat Islam Dalam Pergerakan Nasional Indonesia", Skripsi, (Surabaya Fak.Adab IAIN Sunan Ampel, 1987), h.96. 
pemerintah Kolonial Belanda sebagai pihak penjajah dengan rakyat Indonesia sebagai pihak yang dijajah, Juga adanya benturan kemauan antara penjajah yang berusaha untuk melanjutkan kekuasaannya di tanah jajahannya sedangkan yang dijajah berusaha untuk mencapai kemerdekaannya. untuk mencapainya tidak mungkin penjajah mau membantu dalam usahanya tersebut, oleh karena itu makin memperbesar semangat nasionalisme mereka dalam memperjuangkan untuk mencapai kemerdekaan, sebagaimana terlihat denga dilaksanakannya kegiatan radikal oleh kaum pergerakan, bersikap non koperasi dan usaha-usaha memperbesar kekuatan nasional, baik melalui usaha mempererat persatuan dan kesatuan nasional, maupun melalui usaha memperkuat ekonomi dan status sosial rakyat Indonesia.

\section{Simpulan}

Sarekat Islam merupakan organisasi pergerakan nasional Indonesia yang pertama dalam arti sesungguhnya, hal itu dapat dibuktikan dengan segala sesuatu yang diperjuangkan adalah semata ditujukan untuk rakyat Indonesia, yang di dalam perjuangannya tersebut memperoleh dukungan dari rakyat banyak sehingga dapat mendorong segera terciptanya kesadaran nasional di Indonesia.Kesuksesan yang diraih oleh Sarekat Islam dalam ikut serta mewujudkan persatuan nasional rakyat Indonesia, Pada masa awal pergerakan nasional adalah melalui ikatan keagamaan yang dalam hal ini adalah agama Islam.agama telah mampu merendam perselisihan dan perbedaan yang ada di antara mereka, Ia mempunyai arti penting bagi rakyat Indonesia di dalam penyatuan Indonesia.Sarekat Islam sebagai organisasi sosial politik umat Islam Indonesia, di dalam perjuangannya bergerak pada seluruh segi bidang kehidupan masyarakat rakyat Indonesia, seperti di bidang ekonomi, sosial, budaya, politik dan keagamaan. Penekanan diantara bidang-bidang kegiatannya tersebut, dilaksanakan sesuai kondisi dan daya penerimaan rakyat serta dengan memperhatikan reaksi dari pihak pemerintah kolonial Belanda, Hal itu merupakan sebuah strategi perjuangan Sarekat Islam di dalam upayanya untuk mencapai kemerdekaan Republik Indonesia.

Perjuangan Sarekat Islam dalam pergerakan nasional telah mampu menumbuhkan kesadaran rakyat Indonesia terhadap nilai manusia dan harga dirinya sebagai suatu bangsa.kesadaran itu selanjutnya berkembang menjadi kesadaran nasional dengan tumbuhnya ikatan persatuan nasional di antara rakyat Indonesia. Perjuangan Sarekat Islam juga menyadarkan pihak pemerintah kolonial Belandaterhadap keinginan yang hidup di hati rakyat Indonesia untuk mencapai kemerdekaannya. Sarekat Islam juga ikut terlibat dalam pergerakan nasional tidak terlepas dari hambatan dan tantangan yang perlu mendapatkan 
banyak perhatian, hambatan dan tantangan itu baik yang datang dari pihak pemerintah kolonial Belanda dengan berbagai usahanya untuk membatasi dan menguasai gerak perjuangan Sarekat Islam maupun yang datang dari anggotanya sendiri dengan wujud terjadinya beberapa kali perpecahan dalam tubuh Sarekat Islam sehingga melemahkan intensitas perjuangannya di dalam pergerakan nasional meskipun demikian Sarekat Islam tetap mempunyai peranan penting di dalam mewujudkan kemerdekaan Republik Indonesia, karena jika membaca penjelasan sebenarnya dapat disimpulkan Sarekat Islam adalah Pengagas Nasionalisme Indonesia.

\section{Daftar Pustaka}

Ahmad Mansur Suryanegara, Api Sejarah (Mahakarya Perjuangan Ulama dan Santri DalamMenegakkan Negara Kesatuan Republik Indonesia, Vol. 1 (cet. Iv, Bandung : Penerbit Surya Dinasti.2018)

Anton Timur Djaelani, Gerakan Sarekat Islam (Cet; I Jakarta: LP3ES, 2017).

Ahmad Mansur Suryanegara, Api Sejarah (Mahakarya Perjuangan Ulama dan Santri DalamMenegakkan Negara Kesatuan Republik Indonesia, Vol. 1 (cet. Iv, Bandung : Penerbit Surya Dinasti.2018)

Almez H.O.S Tjokroaminoto Hidup dan Perjuangannya, (Vol. 1, Jakarta: Bulan Bintang, 1952).

A. P.E. Korver, Sarekat Islam Sebagai Ratu Adil, (Jakarta, Grafiti Press, 1985)

Deliar Noer, Gerakan Modern Islam di Indonesia 1900-1942, (Jakarta, LP3S, 1980) Harun Nasution, "Pembaharuan dalam Islam Sejarah Pemikiran dan Gerakan", dalam Muhammad Tamrin, "Islam dan Nasionalisme Indonesia", Skripsi (Ujung Pandang, Fak. Adab IAIN Alauddin”,1997)

Lothrop Stoddard, DuniaBaru Islam, (Jakarta: PanitiaPenerbitDuniaBaru Islam, 1996)

Kahin, Nationalism and revolution in Indonesia.

Margono.Ictisar Sedjarah Pergerakan Nasional (1908-1945) (Jakarta: Dephankan Pusat Sejarah ABRI, 1971)

Moh. Yusuf, "Sarekat Islam Dalam Pergerakan Nasional Indonesia”, Skripsi, (Surabaya Fak. Adab IAIN Sunan Ampel, 1987)

Moh. Yusuf, "Sarekat Islam Dalam Pergerakan Nasional Indonesia", Skripsi, (Surabaya Fak. Adab IAIN Sunan Ampel, 1987) 
Muhammad, Tamrin, "Islam danNasionalisme Indonesia", Skripsi(Ujung Pandang:Fak. IAIN Alauddin, 1997)

Muhammad Roem, Tiga Peristiwa Bersejarah, (PT. Sinar Hudaya, 1972)

Novian Dwi Cahyo,"Peranan H. Samanhudi dalam Sarekat Dagang Islam”, Skripsi (Makassar Fak. Adab dan Humaniora UIN Alauddin, 2018). 